\title{
CNRS launches new strategy to break with its past
}

Paris. Europe's largest fundamental research organization, France's Centre National de la Recherche Scientifique (CNRS), last week launched an ambitious plan to increase its operating flexibility, continue its decentralization away from Paris, and build closer links with universities and industry.

Each of these represents a major step towards the "liberalization" of the organization and a shift away from past UNAVAILABLE operating practices. But how effective the plan will be depends on the ability of both the CNRS and the government to overcome obstacles to change, in conditions under which the CNRS

operates and the terms of the employment of its scientists.

The plan, which outlines the CNRS's strategy for the period up to the end of 1995 , was published in Paris last week. One commitment is to increase support for several interdisciplinary themes - such as understanding complexity - and raise its efforts to integrate mathematics, computing, and new technologies into all scientific disciplines (see box).

The goals of the plan are mainly drawn from last year's Rapport de Conjoncture, a 500 -page review of international trends in research based on a wide-ranging consultation with CNRS scientists. A new element in CNRS thinking is the official encouragement being given to scientists to take more interest in the social and economic implications of their research.

François Kourilsky, director-general of CNRS, says it has become essential for researchers to consider the social acceptparticular the legal

ability of technology if they are to avoid a public backlash against their work. "We are certainly in favour of the fundamental research needed to develop new technologies, but not at any price", he says. "Technology must be adapted to man's needs, not the reverse."

Kourilsky says he would like to bring researchers together into interdisciplinary programmes with an explicit social dimension. In particular, he wants to see more social scientists, who make up one-sixth of CNRS research staff, participating in experimental research programmes. "I wish some of them would spend less time studying the sociology of the thirteenth century and more time on today's problems."

The emphasis being placed by CNRS on the relevance of its work to social issues is partly intended to reassure politicians and public of the value of basic research, particularly at a time when France's economic crisis is biting into public spending. "We have to defend research", says Kourilsky.

For the same reason, CNRS's new strategy emphasizes the importance of basic research in creating technology and jobs, pointing out that it has increased the value of its contracts with industry from FF39 million (US\$7 million) in 1983 to FF550 million last year.

CNRS has also, for the first time, been consulting with industry over its choice of research priorities. For example, it accepted the advice of industries based on the life sciences not to focus excessively on human genetics at the expense of more traditional fields such as basic microbiology.

Perhaps the most radical aspect of the new strategy is the strong encouragement to be given to research workers to take up either temporary or permanent positions in universities. CNRS may have little choice. François Fillon, the minister for higher education and research, is expected to stipulate targets for such transfers within the pro-

\section{French labs face funding squeeze}

Paris. The small increase in the 1994 French budget for science (Nature 356, 378; 1993) will help the immediate cashflow of the Centre National de la Recherche Scientifique (CNRS). But it will seriously restrict any new initiatives next year.

CNRS says that the budget translates into a 2.5 per cent cut in operating expenses, a 3.7 per cent cut in programme authorizations and a 3.8 per cent increase in actual cash payments. These compare to the anticipated rate of inflation of 2.2 per cent.

The increase in cash payments will let the
CNRS make up most of last year's shortfall. But the cut in programme authorizations will mostly fall on laboratories, says CNRS, because it cannot reduce its commitments to international big science projects. postdoctoral fellowships have also been frozen. Indeed, some French researchers are concerned that the CNRS will not be able to continue to provide additional support to laboratories that have already agreed to take on foreign postdoctoral fellows.

Declan Butler
Plans for a large increase in foreign

\section{The CNRS strategic plan, $1993-1995$}

Science:

- Understanding complexity (from molecules to mathematics)

- Development of technologies and processes better adapted to human needs

- The main challenges facing society (the environment, killer diseases, ageing, cities, unemployment)

- Big science (astronomy, particle physics)

- New tools and new technologies for research (large equipment, mathematical modelling, electronic highways, databases, nanotechnology, robotics)

Policy:

- Greater collaboration with other research organizations and industry

- Decentralization and internationalization

- Dissemination of science in society

- More active personnel management

- Merger of groups of laboratorles into semi-autonomous research instltutes

posed five-year contracts between his ministry and the CNRS and other research organizations (see Nature 365, 196; 1993).

Only 40 or so CNRS researchers transferred to universities last year. Kourilsky favours greater mobility in both directions, and has already increased incentives for the agency's researchers to take on teaching duties.

He also sees Fillon's demand for greater collaboration with universities as a solution to the staff logjam within the CNRS. The agency spends three-quarters of its budget on salaries, leaving little money for research funding. The small growth in next year's budget has narrowed the margin further.

Kourilsky admits there is a strong case for reducing staff numbers. But he points out the difficulty of doing this, given that all CNRS employees are civil servants, and therefore enjoy full job security. His plan is to reward the best researchers with rapid promotion, and provide incentives for the less productive ones to take up teaching posts in universities or to enter other public services.

Roland Tourreau, from the researcher's union SGEN-CFDT, says that the union generally supports such moves. But CNRS has little experience of the sort of case-bycase personnel management that implementing this policy would require. And given overall budgetary constraints, its success in doing so - as in shifting resources into priority areas - also depends on whether Fillon is able to secure changes in legislation to give CNRS greater responsibility to manage and spend its budget.

Declan Butler 